\title{
Impact of Environment Conditions on Grapevine (Vitis vinifera L.): To Optimal Production and Sustainability, Achieving Food Security and Increasing the Palestinian Economy
}

\author{
Jehad M. H. Ighbareyeh ${ }^{1,2^{*}}$, Eusebio Cano Carmona ${ }^{1}$ \\ ${ }^{1}$ Department of Animal and Plant Biology and Ecology, Faculty of Experimental Sciences, University of Jaen, Jaen, Spain \\ ${ }^{2}$ Department of Plant Production and Protection, Faculty of Agriculture, Al-Quds Open University, Abu ktellah Street, Hebron, \\ Palestine \\ Email: *jehadighbareyeh@hotmail.com
}

How to cite this paper: Ighbareyeh, J.M.H. and Carmona, E.C. (2018) Impact of Environment Conditions on Grapevine (Vitis vinifera L.): To Optimal Production and Sustainability, Achieving Food Security and Increasing the Palestinian Economy. Journal of Geoscience and Environment Protection, 6, 62-73.

https://doi.org/10.4236/gep.2018.62005

Received: December 26, 2017 Accepted: February 25, 2018

Published: February 28, 2018

Copyright $\odot 2018$ by authors and Scientific Research Publishing Inc. This work is licensed under the Creative Commons Attribution International License (CC BY 4.0).

http://creativecommons.org/licenses/by/4.0/

\begin{abstract}
Grapevine (Vitis vinifera L.) is one of important economic fruit crops found in Hebron of Palestine. Climate is one of the key controlling factors in grape and wine production. Materials \& Method: We analyzed grape production in Hebron region, and studied the correlation analyses between productions and climatic, bioclimatic factors. The bioclimate, climatic factors were obtained according to Rivas-Martinez to classification of the earth. However, the independent variables were examined: the bioclimate factors as compensated thermicity index, annual ombrothermic index, water deficit and simple continentality index; and following climate factors: mean monthly temperature, precipitation and soil water reserve. The data used were from one meteorological station of the Palestinian Meteorological Department for the years 1993 to 2009 (16 years), and to the same years of grape production (rain-fed) from the Palestinian Central Bureau of Statistics (PCBS). Result \& Discussion: When we applied a Principal Component Analysis (PCA), and observed that the Hebron type plots are located at the left of axis 1 during 1999-2004 negatively affected by the bioclimate factors as compensated thermicity index, with a large proportion of the variance explained by axes 1 (76.66\%), but precipitation was positive influenced on grape yield for the years (2004-2009), with a proportion of the variance explained by axes 2 (23.34\%); Hebron type plots are located at the right of axis1during 1993-1999 positive affected by the bioclimate factor as a simple continentality index and annual ombrothermic
\end{abstract}


index, and climate factors as water deficit, soil water reserve and mean monthly temperature, with a large proportion of the variance explained by axes $1 \& 2$ (100\%). Conclusions: Grapes are sensitive climate and the surrounding environment factors, and in order to get a high production and high-quality grapes, mean monthly temperature must be between $15^{\circ} \mathrm{C}-20^{\circ} \mathrm{C}$, and $20^{\circ} \mathrm{C}-30^{\circ} \mathrm{C}\left(27^{\circ} \mathrm{C}\right)$ in the last two months of the maturation process, the value of simple continentality index is $15-18$, compensated thermicity index is $220-350$, and annual ombrothermic index is more than 3.

\section{Keywords}

Palestine, Hebron, Grapes, Food Security, Economy, Climate

\section{Introduction}

A grape (Vitis vinifera L.; Vitaceae) is a fruit, botanically a berry, of the deciduous woody vines of the flowering plant genus Vitis. The cultivation of the domesticated grape began 6000 - 8000 years ago in the Near East [1]. The earliest archeological evidence for a dominant position of wine-making in human culture dates from 8000 years ago in Georgia [2] [3], Ancient Egyptian, and the West Asia region as Syria, and Palestine where it has existed since the Canaanite era; furthermore ancient Egypt was supplied with Palestinian wine as early as Chalcolithic, the Early and Late Bronze Ages [4], and Egyptians from the 15th century BCE described the wine of Canaan as being "more abundant than water" [4]. However, most Vitis species are found in the temperate regions of the Northern Hemisphere in Asia, North America and with a few in the tropics regions in the world, also grapevines are influenced to their surrounding environment with a seasonal variation in production of $30 \%-32.5 \%$ [5]. Climate is one of the key controlling factors in grape yields [6], affecting the suitability of certain grape varieties to a particular region as well as the type and quality of the wine produced. A few years ago, many researchers in Mediterranean region have studied the relationship between plant production (fruit trees), physiology, plant biology [7]-[26], biodiversity, phytosociological, plant communities and climate-bioclimate factors [8] [9] [10], and biologically, most Vitis species have 38 chromosomes $(n=19)$ [27], while Vitis rotundifolia has $40(n=20)$.

According to the Food and Agriculture Organization (FAO), $75,866 \mathrm{~km}^{2}$ of the world are dedicated to grapes, of which $71 \%$ of world grape production is used for wine, $27 \%$ as fresh fruit, and $2 \%$ as dried fruit. Over the past few years, China, the United States, Turkey, South Africa, Argentina and some European countries such as Spain, Italy and France have been among the world's top grape producers (Figure 1) [28].

In Palestine, grapes are the second crop after olives in terms of production and economic importance, and constitute $36.4 \%$ of total agricultural land cultivated in 


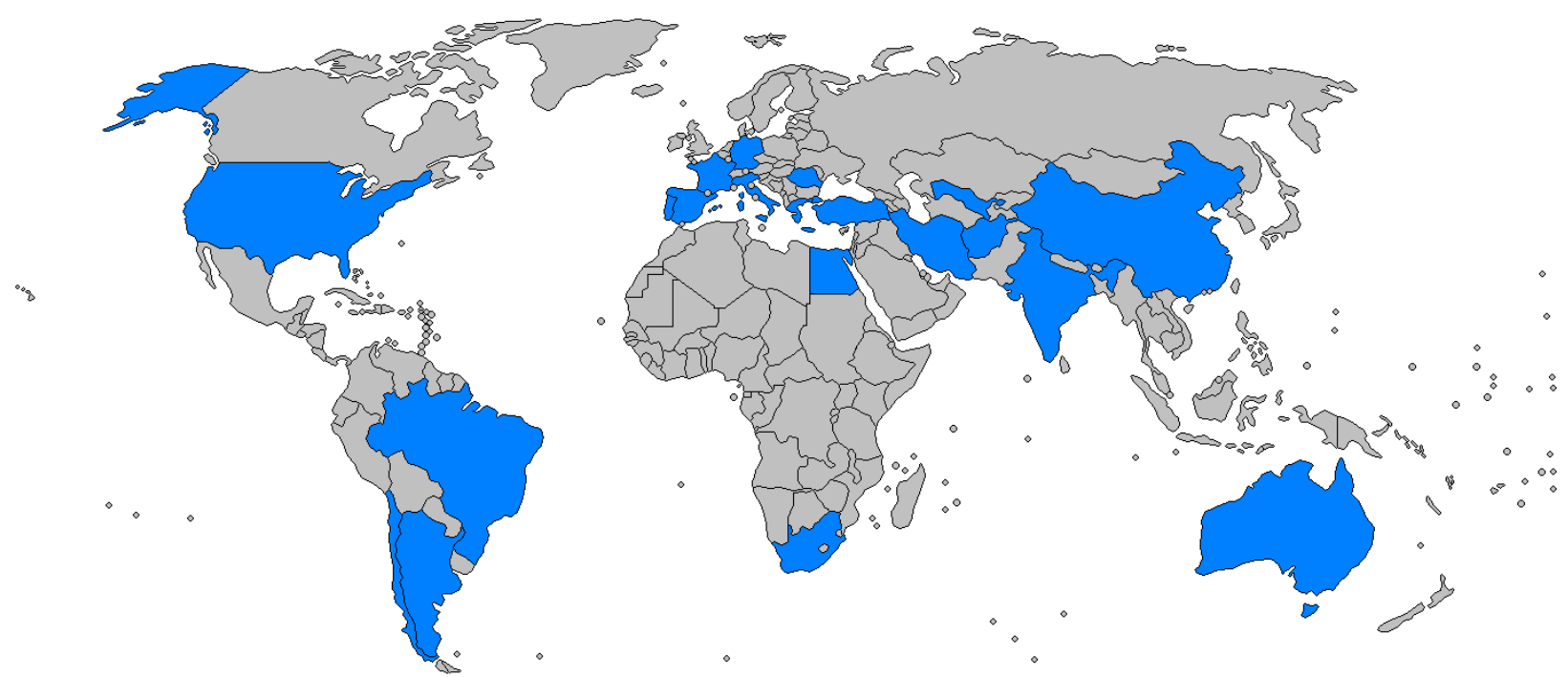

Figure 1. Top 20 grape producing countries (blue color) in 2012 by FAO in the world [28].

the West Bank [29]. The annual total production of grapes is estimated at 50,065 tons in the West Bank, representing $9 \%$ of total production of all targeted crops. Hebron region is the highest producer of grapes, constituting $58 \%$ of total production, followed by Bethlehem province (27\%), and Jenin province (6\%) [30].

Analyses of the present work are to: i) analyze the physical factors of Hebron bioclimate; ii) study the relationship between the climate, bioclimate factors and grapes yield to maintain and achieve food security in Hebron of Palestine.

\section{Materials \& Methods}

\subsection{Study Area}

Hebron is located between longitudes $35^{\circ} 05^{\prime} 42^{\prime \prime}$ east and latitude $31^{\circ} 32^{\prime}$ north in the southern West Bank, $30 \mathrm{~km}$ south of Jerusalem, it lies 930 meters above sea level, area of $74.102 \mathrm{~km}^{2}$ (28.611 sq. mi (Square Miles), it is the largest city in the West Bank, and the second largest in the Palestinian state after Gaza strip. Historically, Hebron (older Hebron) was originally a Canaanite royal city [31], archaeological excavations reveal traces of strong fortifications dated to the Early Bronze Age, covering some 24 - 30 dunams centered around Tel Rumeida, and the city flourished in the $17^{\text {th }}-18^{\text {th }}$ centuries BCE before being destroyed by fire, and was resettled in the late Middle Bronze Age [32] [33].

\subsection{Data Collection and Analysis}

In this work, we analyzed grape production in Hebron Territories, and studied the correlation analyses between production and climatic, bioclimatic factors. The independent variables were examined the following climate, bioclimate factors, climate factors: Mean monthly temperature (T), precipitation $(\mathrm{P})$ and soil water reserve (R); and bioclimatic factors as compensated thermicity index (It/Itc), annual ombrothermic index (Io), simple continentality index (Ic) and 
water deficit (Df). However, the data used were from one meteorological station of the Palestinian Meteorological Department for the years 1993 to 2009 (16 years), and to the same years of grape production (rain-fed) from the Palestinian Central Bureau of Statistics (PCBS) (Figure 2) and (Table 1). The study was dependent on the correlation analyses between grape production in one station (Hebron) over sixteen years, and the bioclimate, climatic factors were obtained according to Rivas-Martinez to classification of the earth (http://www.globalbioclimatics.org) [34]-[39]. In addition, we applied the Shapiro-Wilk and Jarque-Bera normality tests [40] [41] [42] [43], the p-value was obtained for the eight variables. Furthermore, we applied an ANOVA linear regression analysis to each of the eight

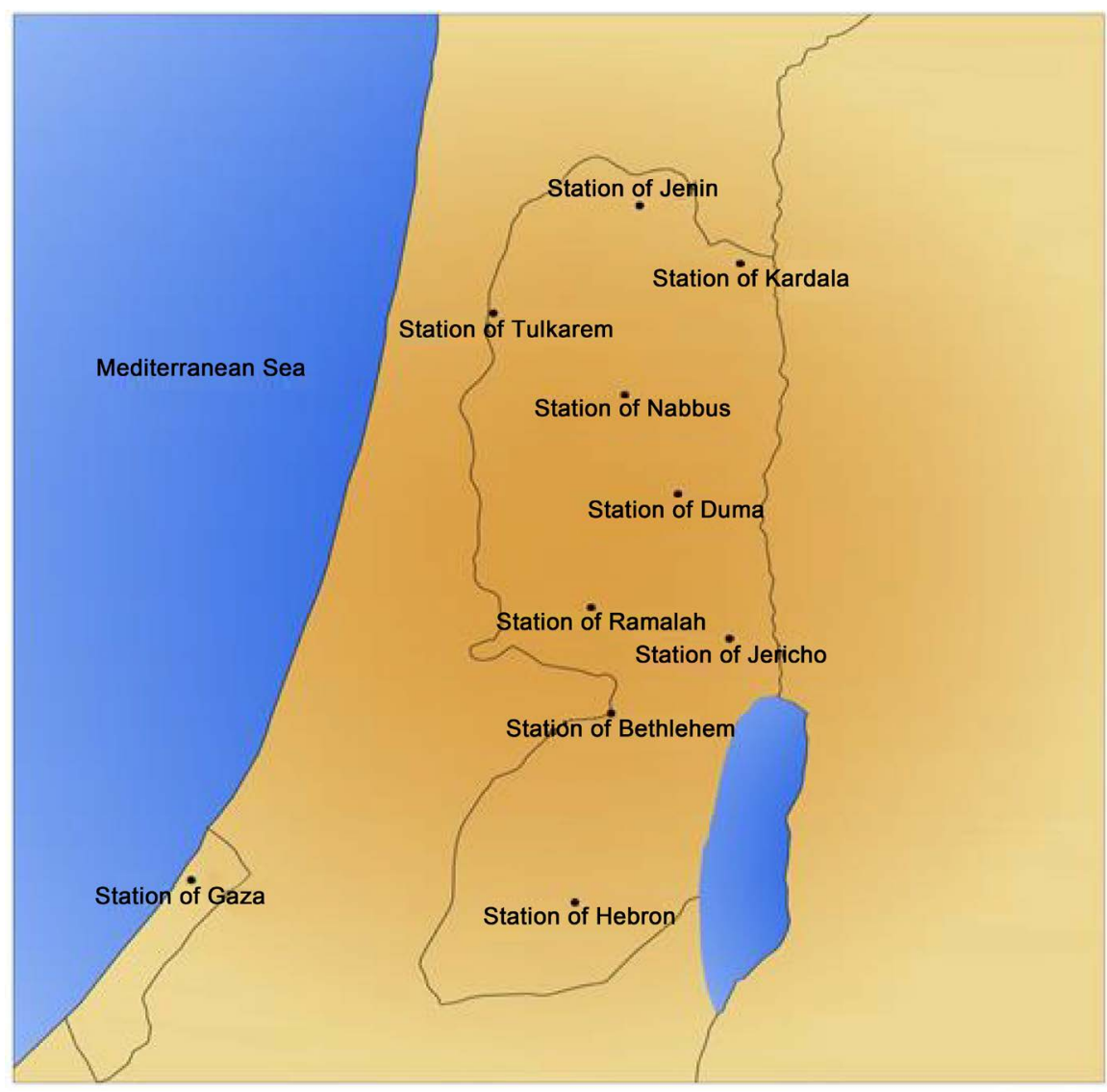

Figure 2. Location of the meteorological Hebron station.

Table 1. Represents of independents variables (bioclimate factors as annual ombrothermic index, simple continentality index, deficit water, and compensated thermicity index, and climate factors as a mean monthly temperature, precipitation, and soil water reserve); dependents variable is consist of grape production.

\begin{tabular}{ccccccccc}
\hline Years & T & P & Df & R & It/Itc & Ic & Io & Grape P. \\
\hline $1993-1999$ & 16.7 & 601 & 650 & 430 & 299 & 18 & 3 & 688 \\
$1999-2004$ & 16.5 & 595 & 640 & 417 & 350 & 17 & 3.1 & 804 \\
$2004-2009$ & 16.4 & 598 & 610 & 410 & 311 & 17 & 3.4 & 847 \\
\hline
\end{tabular}

Productivity: kg/dunum, dunums: $1000 \mathrm{~m}^{2}$, and P: Production. 
variables (independent and dependent variables), the three bioclimatic variables and the four remaining physical variables (climate factors), and the dependent variable as grape production, to obtain principal component analysis and correlation variables were subsequently applied to determine the effect of independent variables on grape production, and using XLSTAT software, statistical analyses were done in these study.

\section{Result and Discussion}

\subsection{Effect of Climate \& Bioclimate Factors on Grapes Production}

\section{Principal Component Analysis (PCA)}

In the general, by using the bioclimatic classification of earth to Salvador Rivas-Martinez to analyses of the climate factors and bioclimatic parameters or variables, and we obtained p-value from the variables studied tended to be below 0.05 , the odds are conventionally accepted to value, after application of the Shapiro-Wilk normality test [40] [41] [42] [43]. PCA is mostly used as a tool in exploratory data analysis, covers standard deviation, covariance, eigenvectors and eigenvalues, and others.

\section{Eigenvectors and eigenvalue}

Eigenvalues and eigenvectors play a prominent role in the study of ordinary differential equations and in many applications in the physical sciences. Furthermore, calculate of the Eigenvectors and eigenvalue given by: Let $M$ be an $n \times$ $n$ matrix. $A$ is there is a nontrivial solution $x$ of $A x=\lambda x$. Where, $V$ is an eigenvector of $M$ if $M \times v=\lambda v, \lambda$ is called the eigenvalue associated with $v$.

For any eigenvectors $v$ of $M$ and scalar $a, M \times a v=\lambda a v$. Thus you can always choose eigenvectors of length 1 :

$$
\sqrt{v_{1}^{2}+\cdots+v_{n}^{2}}=1
$$

If $M$ has any eigenvectors, it has $n$ of them, and they are orthogonal to one another, thus eigenvectors can be used as a new basis for an n-dimensional vector space. And $A X=\lambda X$, for some scalar $\lambda$. The scalar $\lambda$ is called an eigenvalue of $A$, and $x$ is called the eigenvector of $A$ corresponding to the eigenvalue $\lambda$.

However, PCA was used to help identify the variables different, using factor extraction with an eigenvalue $>1$ after varimax rotation. The results of principal component analysis, including the factor loadings with a varimax rotation as well as the eigenvalues, are tabulated in (Table 2), two of the eigenvalues were found to be $>1$, and the total variance for the two factors is about $76.659 \%$.

Moreover, factor 1 was dominated by climate, bio-climate factor as precipitation (0.031), mean monthly temperature (0.031), water deficit $(0.022)$, soil water reserve (0.037), annual ombrothermic index (0.066) and simple continentality index (0.058) excepted compensated thermicity index $(-0.014)$, with accounts $(0.002)$ of eigenvalue and $(76.659 \%)$ to the total variance or variability. Factor 2 is a positive dominated by water deficit $(0.016)$, soil water reserve $(0.006)$, but negatively to the rest of factors as compensated thermicity index $(-0.057)$, an- 
nual omrothermic index $(-0.011)$ and simple continentality index $(-0.009)$, with accounts $(23.341 \%)$ of the total variance, as tabulated in Table 2 \& Figure 3.

In the other side, when we applied a Principal Component Analysis (PCA), observed that the Hebron type plots are located at the left of axis 1 during (1999-2004) affected negatively by the bioclimate factors as compensated thermicity index, which negatively affected the grape harvest for this occurred in the $y$-axis negative, with a large proportion of the variance explained by axes 1 (76.66\%), but precipitation was a positive effect on grape yield for this occurred

Table 2. Factors of eigenvectors and eigenvalue of the principal component analysis and variables data (dependent and independent variables).

\begin{tabular}{ccc}
\hline Variables & F1 & F2 \\
\hline $\mathrm{T}$ & 0.031 & -0.011 \\
$\mathrm{P}$ & 0.031 & -0.004 \\
$\mathrm{Df}$ & 0.022 & 0.016 \\
$\mathrm{R}$ & 0.037 & 0.006 \\
$\mathrm{It} / \mathrm{Itc}$ & -0.014 & -0.057 \\
$\mathrm{Ic}$ & 0.058 & -0.009 \\
Io & 0.066 & -0.011 \\
Grapes production & -0.058 & 0.010 \\
Eigenvalue & 0.002 & 0.000 \\
Variable (\%) & 76.659 & 23.341 \\
Cumulative\% & 76.659 & 100 \\
\hline
\end{tabular}

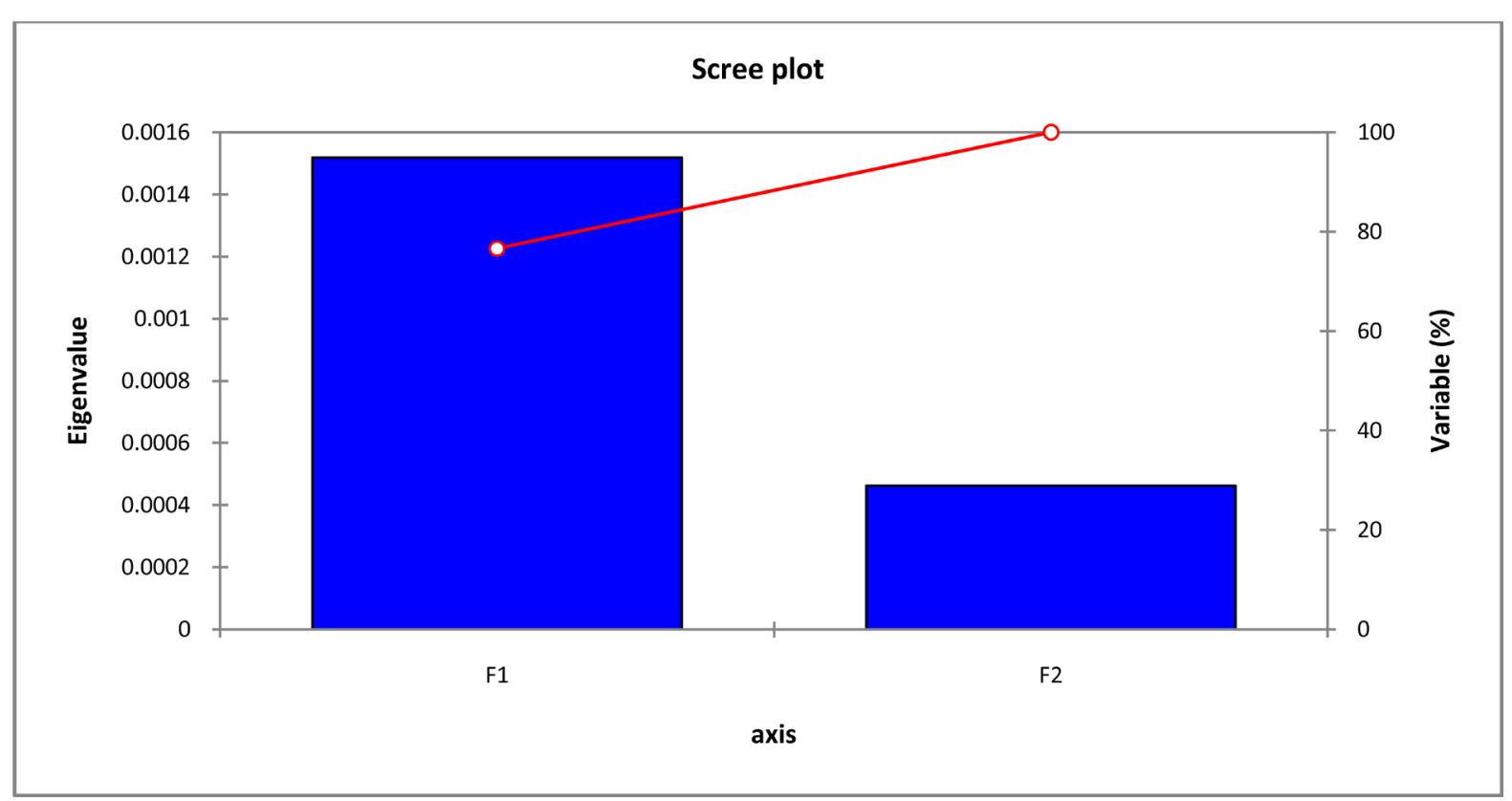

Figure 3. Graphic representing the eigenvalue of the principal component analysis and data variables. 


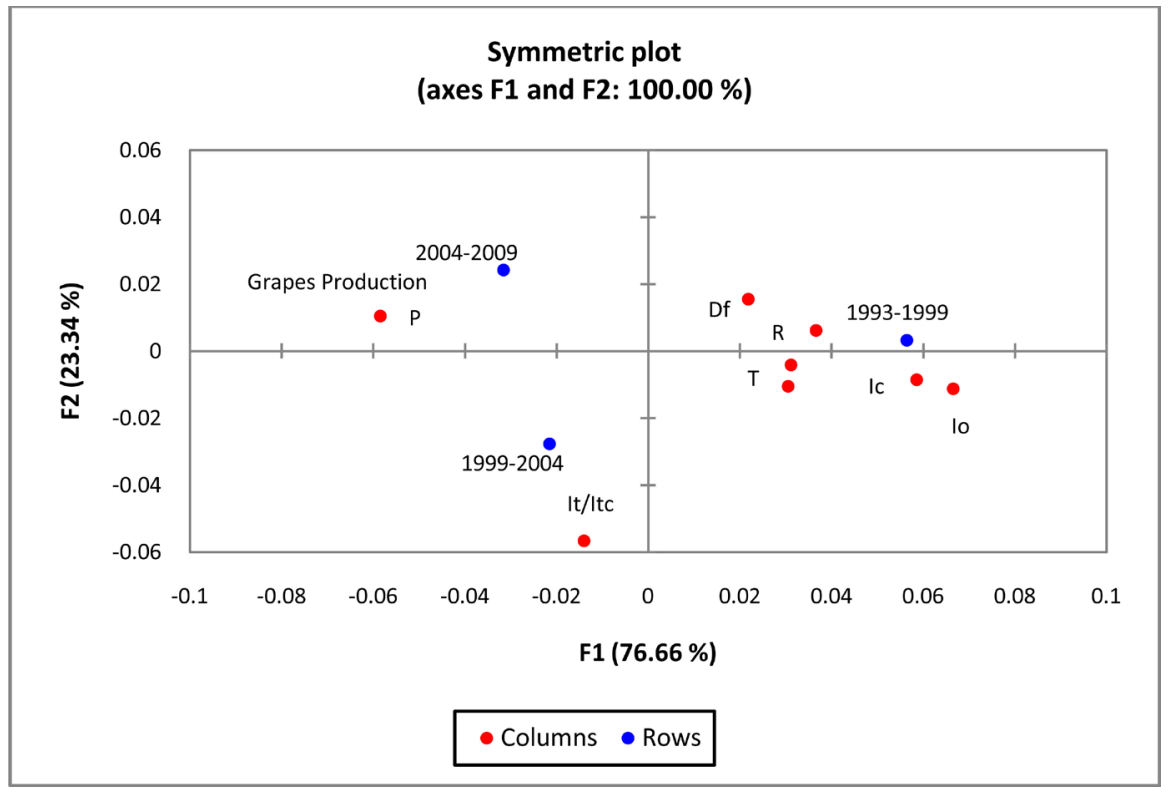

Figure 4. Graphic of principal component analysis using both eigenvectors and biplot axes of a new data points variables.

in the y-axis positive during the year (2004-2009), with a proportion of the variance explained by axes 2 (23.34) Hebron type plots are located at the right of axis1during (1993-1999), which has a positive effect on the grapes yield by bioclimate factors as a water deficit, simple continentality index and annual ombrothermic index, and climate factors as a soil reserve water and mean monthly temperature, also these factors have a positive effect on the grape because it lies in the positive $\mathrm{X}$-axis, with a large proportion of the variance explained by axes 1 \& $2(100 \%)$ (Figure 4$)$. In this analysis we also observed that the bioclimate, climate factors have a positive effect on the production of grapes except compensated thermicity index, that's means grape are environmental adapted in mesomediterranean with the value of compensated thermicity index is $210 / 350$, annual ombrothermic index $<3$, simple thermicity index is $15-18$, mean monthly temperature is $15^{\circ} \mathrm{C}-20^{\circ} \mathrm{C}$, and with precipitation is $450-950 \mathrm{~mm}$., for this, grapevine is one of the plants fruit trees affected by climatic, bioclimatic [7] [10] and biological factors [5].

\subsection{Impact of Temperature on Grapes}

However, in our study, it is clear that the optimum mean monthly temperature ranging from $15^{\circ} \mathrm{C}-20^{\circ} \mathrm{C}$ to produce grapes with a high quality, and that optimum mean monthly temperature during the last two months to the maturity of the crop ranges between $20^{\circ} \mathrm{C}-30^{\circ} \mathrm{C}\left(27^{\circ} \mathrm{C}\right)$, and a high levels are positively correlated to commercial quality, and the temperature between $\left(10^{\circ} \mathrm{C}-12^{\circ} \mathrm{C}\right)$ is the starting point of growth and activity of the grape buds. Warmer climates $\left(21^{\circ} \mathrm{C}-24^{\circ} \mathrm{C}\right)$, are lead to a high grape sugar and low acidity which makes a very sweet product but lacks to colour and subtlety in some of Europeans countries 
(southern Spain), Asia countries, southern California and Cyprus, therefore grapes need sustained warmth to ensure a high sugar content in the fruit for convert it into alcohol, also the grape does not ripen properly, leading to too much acidity especially when the climate is cold and the temperature less than $15^{\circ} \mathrm{C}$ in the final month of grape maturity.

Furthermore, in the spring when the mean daily temperature reaches $10^{\circ} \mathrm{C}$, rapid growth of shoots takes its places, about seven to eight weeks later, and when mean daily temperature has risen to about $20^{\circ} \mathrm{C}$, flower clusters bloom, whereas when the temperature is low $-18^{\circ} \mathrm{C}$ grape can be tolerated for short periods whilst in spring $-4^{\circ} \mathrm{C}$ will kill young leaves, and $-2^{\circ} \mathrm{C}$ will damage emerging flower clusters [44].

Moreover, research has shown that grapevines exposed to temperature consistently around $30^{\circ} \mathrm{C}$ had significantly lower concentrations of anthocyanin's compared to grapevines exposed to temperatures consistently around $20^{\circ} \mathrm{C}$ [45]. Temperatures around or exceeding $35^{\circ} \mathrm{C}$ are found to stall anthocyanin production as well as degrade the anthocyanins that are produced [46]. Furthermore, anthocyanins were found to be positively correlated to temperatures between $16^{\circ} \mathrm{C}-22^{\circ} \mathrm{C}$ from change of colour of the berries to harvest [47].

In the end, the fruit of the vine, quantity and quality of the resultant wine is influenced by macro-climate to micro-climatic conditions of the vineyard and also the climate change and the weathers events occurring in each growing season. In the fact, we emphasize that the difference in temperature and climate change in recent years, will negatively affect the grapes and plant production, which leads to food shortages and thus a disruption in food security of Palestine in the future, unless there is a strategy to keep the food security plan. Therefore, there should be careful study of climate factors, water sources, soil type, control of pests, plant diseases, and plant varieties, especially fruit trees, in an integrated manner to determine where plants can be grown according to the ability of plants to adapt to increase production and high quality, hereby achieving food security, increase the national output and Palestinian economy.

\section{Conclusion}

Climate is one of the role controlling factors in grape and grapevine production in Hebron and all over the world. Grapes are sensitive climate and the surrounding environment factors, and in order to get a high production, high-quality grapes and achieve food security, grapes were adapted in places where the mean monthly temperature is between $15^{\circ} \mathrm{C}-20^{\circ} \mathrm{C}$, with $20^{\circ} \mathrm{C}-30^{\circ} \mathrm{C}\left(27^{\circ} \mathrm{C}\right)$ during the last two months of the maturation process, the value of simple continentality index is between $15-18$, compensated thermicity index is $220 / 350$, annual ombrothermic index is more than 3, and rainfall is between $500-900 \mathrm{~mm}$; therefore, grapes are adapted to the Meso-Mediterranean environmental areas in the world. Furthermore, Hebron grapes are the finest grapes in the world, because it has all the best international standards, and the climates of Hebron and Bethle- 
hem are one of the best climatic conditions for the production of high quality grapes in the world, due to the appropriate temperature, soil type and other climatic, bioclimate factors. However, Hebron has a unique biodiversity and climate in the world as: i) mountainous highlands, which are affected by the climate of the Mediterranean basin; ii) the eastern region, which is affected by the climate of the Dead Sea and the Jordan Valley; iii) the western region, which is affected by the climate of the Palestinian coast and the Mediterranean coast; and iv) the southern region, which is affected by the climate of the African Sahara, as Sinai and the Red Sea.

\section{References}

[1] This, P., Lacombe, T. and Thomash, M.R. (2006) Historical Origins and Genetic Diversity of Wine Grapes. Trends in Genetics, 22, 511-519. https://doi.org/10.1016/j.tig.2006.07.008

[2] Keys, D. (2003) Now That's What You Call a Real Vintage: Professor Unearths 8,000-Year-Old Wine.

http://www.independent.co.uk/news/science/now-thats-what-you-call-a-real-vintag e-professor-unearths-8000-year-old-wine-84179.html

[3] McGovern, P.E. (2003) Ancient Wine: The Search for the Origins of Viniculture (PDF). Princeton University Press, Princeton.

[4] Broshi, M. (2001) Bread, Wine, Walls and Scrolls. Continuum International Publishing Group, London, New York.

[5] Chloupek, O., Hrstkova, P. and Schweigert, P. (2004) Yield and Its Stability, Crop diversity, Adaptability and Response to Climate Change, Weather and fertilisation over 75 Years in the Czech Republic in Comparison to Some European Countries. Field Crops Research, 85, 167-190. https://doi.org/10.1016/S0378-4290(03)00162-X

[6] Fraga, H., Malheiro, A.C., Moutinho-Pereira, J. and Santos, J.A. (2014) Climate Factors Driving Wine Production in the Portuguese Minho Region. Agricultural and Forest Meteorology, 185, 26-36. https://doi.org/10.1016/j.agrformet.2013.11.003

[7] Ighbareyeh, J.M.H., Cano-Ortiz, A. and Cano, E. (2014) Biological and Bioclimatic Basis to Optimize Plant Production: Increased Economic Areas of Palestine. Agricultural Science Research Journal, 4, 10-20.

[8] Ighbareyeh, J.M.H., Cano-Ortiz, A. and Cano, E. (2014) Case Study: Analysis of the Physical Factors of Palestinian Bioclimate. American Journal of Climate Change, 3 , 223-231. https://doi.org/10.4236/ajcc.2014.32021

[9] Ighbareyeh, J.M.H., Cano-Ortiz, A., Suliemieh, A.A.A., Ighbareyeh, M.M.H. and Cano, E. (2014) Phytosociology with Other Characteristic Biologically and Ecologically of Plant in Palestine. American Journal of Plant Sciences, 5, 3104-3118. https://doi.org/10.4236/ajps.2014.520327

[10] Ighbareyeh, J.M.H., Cano-Ortiz, A., Suliemieh, A.A.A., Ighbareyeh, M.M.H. and Cano, E. (2015) Assessing Crop Yield Sustainability under the Climatic and Bioclimatic Change in the Area of Palestine. American Journal of Climate Change, 4, 48-56. https://doi.org/10.4236/ajcc.2015.41005

[11] Cano Ortiz, A., Ighbareyeh, J.M.H. and Cano, E. (2014) Bioclimatic Applications and Soil Indicators for Olive Cultivation (South of the Iberian Peninsula) 2014 
Global Advanced Research Journal of Agricultural Science, 3, 433-438. http://garj.org/garjas/index.htm

[12] Ighbareyeh, J.M.H., Cano-Ortiz, A., Suliemieh, A.A.A., Ighbareyeh, M.M.H. and Cano, E. (2015) Study of Biology and Bioclimatology of Date Palm (Phoenix dactylifera L.) to Optimize Yield and Increase Economic in Jericho and Gaza Cities of Palestine. International Journal of Research Studies in Biosciences, 3, 1-8. http://www.arcjournals.org

[13] Ighbareyeh, J.M.H., Cano-Ortiz, A., Suliemieh, A.A.A., Ighbareyeh, M.M.H. and Cano, E. (2015) Assessment of Biology and Bioclimatology of Plant to Increase Economic in Palestine. International Journal of Research Studies in Biosciences, 3, 1-8. http://www.arcjournals.org

[14] Ighbareyeh, J.M.H., Cano-Ortiz, A., Suliemieh, A.A.A., Ighbareyeh, M.M.H. and Cano, E. (2015) Biology and Bioclimatology Applied on Plant in Palestine. International Journal of Research Studies in Biosciences, 3, 79-86.

http://www.arcjournals.org

[15] Ighbareyeh, J.M.H., Cano-Ortiz, A., Suliemieh, A.A.A., Ighbareyeh, M.M.H. and Cano, E. (2015) Study Effect of Biology and Bioclimatology Applied on Plant in the Area of Hebron at the South of Palestine. International Journal of Research Studies in Biosciences, 3, 56-64. http://www.arcjournals.org

[16] Ighbareyeh, J.M.H., Cano-Ortiz, A., Suliemieh, A.A.A., Ighbareyeh, M.M.H. and Cano, E. (2015) Effect of Biology and Bioclimatology Applied on Plant in the Area of Jenin at the North of Palestine. International Journal of Research Studies in Bioscience, 3, 1-6. http://www.arcjournals.org

[17] Ighbareyeh, J.M.H., Cano-Ortiz, A., Suliemieh, A.A.A., Ighbareyeh, M.M.H. and Cano, E. (2015) Study of Climatology and Bioclimatology Applied on Plant in Area of Hebron in Palestine. International Multidisciplinary Research Journal, 5.

[18] Ighbareyeh, J.M.H., Cano-Ortiz, A., Cano Carmona, E., Ighbareyeh, M.M.H. and Suliemieh, A.A.A. (2015) Modeling of Biology and Bioclimatology Applied on Plant in Palestine. Swift Journal of Agricultural Research, 1, 21-27. http://www.swiftjournals.org/sjar

[19] Ighbareyeh, J.M.H., Cano-Ortiz, A., Suliemieh, A.A.A., Ighbareyeh, M.M.H. and Cano, E. (2015) Effect of Biology and Bioclimatology Applied Studies on Plant in the Area of Jerusalem in Palestine. International Journal of Research Studies in Biosciences, 3, 135-140. http://www.arcjournals.org

[20] Ighbareyeh, J.M.H., Cano-Ortiz, A., Cano, E., Ighbareyeh, M.M.H. and Suliemieh, A.A.A. (2016) Effect of Biology, Climatic and Bioclimatic Applied Studies on Plant: To Increase the Economy and Maintaining Food Security in the Jerusalem Occupied of Palestine. International Journal of Research Studies in Biosciences, 4, 54-60. http://www.arcjournals.org

[21] Ighbareyeh, J.M.H., Cano-Ortiz, A., Suliemieh, A.A.A., Ighbareyeh, M.M.H. and Cano, E. (2016) Study of Biology and Bioclimatology Applied of Apricot (Prunus armeniaca L.): To Increase the Economy and Maintaining Food Security in Palestine. International Journal of Research Studies in Biosciences, 4, 12-20. http://www.arcjournals.org

[22] Ighbareyeh, J.M.H., Cano-Ortiz, A., Suliemieh, A.A.A., Ighbareyeh, M.M.H. and Cano, E. (2016) Modeling of Biology and Bioclimatology Applied Studies on Plant in Palestine. International Journal of Development Research, 6, 9585-9590. http://www.journalijdr.com 
[23] Ighbareyeh, J.M.H., Cano-Ortiz, A., Suliemieh, A.A.A., Ighbareyeh, M.M.H., Cano, E. and Shahir, H. (2016) Effect of Bioclimate Factors on Olive (Olea europea L.) Yield: To Increase the Economy and Maintaining Food Security in Palestine. International Journal of Development Research, 6, 10648-10652. http://www.journalijdr.com

[24] Ighbareyeh, J.M.H., Cano-Ortiz, A., Cano Carmona, E., Ighbareyeh, M.M.H., Suliemieh, A.A.A. and Shahir, H. (2017) Impact of Bioclimate and Climate Factors on Plant Yield in the Area of Jenin at the North of Palestine. International Journal of Current Research, 9, 44529-44535.

[25] Ighbareyeh, J.M.H., Cano-Ortiz, A., Cano Carmona, E., Suliemieh, A.A.A. and Ighbareyeh, M.M.H. (2017) Flora Endemic Rare and Bioclimate of Palestine. Open Access Library Journal, 4, e3977. https://doi.org/10.4236/oalib.1103977

[26] Ighbareyeh, J.M.H. and Carmona, E.C. (2017) Impact of Climate and Bioclimate Factors on Apricot (Prunus armeniaca L.) Yield to Increase Economy and Achieve Maintaining Food Security of Palestine. Open Access Library Journal, 4, e4119. https://doi.org/10.4236/oalib.1104119

[27] Bennett, M.D. and Leitch, I.J. (2012) Royal Botanic Gardens, Kew: Plant DNA C-Values Database, Release 6.0. Royal Botanic Gardens, Kew.

[28] FAO (2012) Top 20 Grape Producing Countries in 2012 Archived 2011-07-13 at the Way back Machine.

[29] Palestinian Ministry of Agriculture (2013) Cultivated Area of Targeted Crops $2012 / 2013$.

[30] Palestinian Ministry of Agriculture (2013) Cultivated Area of Targeted Crops $2015 / 2016$.

[31] Towner, Wayne Sibley (2001) Genesis. Westminster John Knox Press, Louisville.

[32] Negev, A. (2001) Archaeological Encyclopedia of the Holy Land. Continuum International Publishing Group, London.

[33] Na'aman, N. (2005) Canaan in the 2nd Millennium BCE. Eisenbrauns.

[34] Rivas Martinez, S., Sanchez Mata, D. and Costa, M. (1999) North American Boreal and Western Temperate Forest Vegetation (Syntaxonomical Synopsis of the Potential Natural Plant Communities of North America, II). Itinera Geobot, 12, 5-316.

[35] Rivas Martínez, S. (1996) Clasificación bioclimática de la Tierra. Folia Bot Matritensis, 16, 1-20.

[36] Rivas Martinez, S. (2004) Worldwide Bioclimatic Classification System. http://www.globalbioclimatics.org

[37] Rivas-Martinez, S. (2008) Global Bioclimatic. http://www.globalbioclimatics.org

[38] Rivas-Martínez, S., Rivas-Sáenz, S. and Penas, A. (2011) Worldwide Bioclimatic Classification System. Global Geobotany, 1, 1-634.

[39] Rivas-Martínez, S. (2005) Notions on Dynamic-Catenal Phytosociology as a Basis of Landscape Science. Plant Biosystems, 139, 135-144. https://doi.org/10.1080/11263500500193790

[40] Jarque, C. and Bera, A. (1980) Efficient Tests for Normality Homoscedasticity and Serial Independence of Regression Residuals. Econometric Letters, 6, 255-259. https://doi.org/10.1016/0165-1765(80)90024-5

[41] Jarque, C. and Bera, A. (1987) A Test for Normality of Observations and Regression Residuals. International Statistical Review, 55, 163-172. 
https://doi.org/10.2307/1403192

[42] Shapiro, S. and Wilk, M. (1965) An Analysis of Variance Test for Normality (Complete Samples). Biometrika, 52, 591-611. https://doi.org/10.1093/biomet/52.3-4.591

[43] Shapiro, S., Wilk, M. and Chen, H. (1968) A Comparative Study of Various Tests for Normality. Journal of the American Statistical Association, 63, 1343-1372. https://doi.org/10.1080/01621459.1968.10480932

[44] Jackson, D. and Schuster, D. (1 981) Grape Growing and Wine Making: A Handbook for Cool Climates. Alister Taylor, Martinborough.

[45] Yamane, T., Jeong, S.T., Goto-Yamamoto, N., Koshita, Y. and Kobayashi, S. (2006) Effects of Temperature on Anthocyanin Biosynthesis in Grape Berry Skins. American Journal of Enology and Viticulture, 57, 54-59.

[46] Mori, K., Goto-Yamamoto, N., Kitayama, M. and Hashizume, K. (2007) Loss of Anthocyanins in Red-Wine Grape under High Temperature. Journal of Experimental Botany, 58, 1935-1945. https://doi.org/10.1093/jxb/erm055

[47] Nicholas, K.A., Matthews, M.A., Lobell, D.B., Willits, N.H. and Field, C.B. (2011) Effect of Vineyard-Scale Climate Variability on Pinot Noir Phenolic Composition. Agricultural and Forest Meteorology, 151, 1556-1567.

https://doi.org/10.1016/j.agrformet.2011.06.010 